\title{
Penerapan Model Pembelajaran Discovery untuk Meningkatkan Keterampilan Proses Sains dan Penguasaan Konsep IPA SMP
}

\author{
Jurmila $^{1) *}$, Hunaidah $^{2)}$, Luh Sukariasih ${ }^{3)}$ \\ 1)*Mahasiswa Pendidikan Fisika Fakultas Keguruan dan Ilmu Pendidikan Universitas Halu Oleo \\ ${ }^{2), 3)}$ Dosen Pendidikan Fisika Fakultas Keguruan dan Ilmu Pendidikan Universitas Halu Oleo \\ *Korespondensi Email: jurmila@gmail.com
}

\begin{abstract}
Abstrak: Penelitian ini bertujuan untuk mendeskripsikan peningkatan penguasaan konsep dan KPS peserta

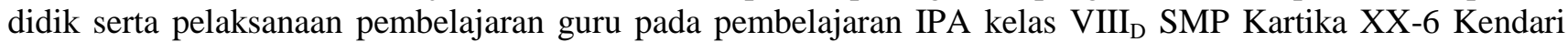
dengan menggunakan model discovery;. Jenis penelitian ini adalah PTK. Subjek dalam penelitian ini adalah seluruh peserta didik tahun ajaran 2018/2019 yang berjumlah 26 orang. Data penelitian adalah data penguasaan konsep yang diperoleh dari tes dan KPS yang diperoleh dari lembar observasi. Analisis data yang dilakukan statistik deskriptif. Hasil analisis data diperoleh bahwa: 1) nilai rerata penguasaan konsep pada siklus I diperoleh nilai 70,07 dengan standar deviasi 9,34 sedangkan pada siklus II nilai rerata penguasaan konsep 77,50 dengan standar deviasi 5,55; 2) presentase aspek keterampilan proses sains pada siklus I yaitu 50,55\% dengan kategori cukup sedangkan pada siklus II yaitu 73,41\% berada pada kategori baik; dan 2) nilai rerata pelaksanaan pembelajaran guru pada siklus I yaitu 2,8 dan pada siklus II yaitu 3,57.
\end{abstract}

Kata Kunci: Keterampilan Proses Sains; Model Pembelajaran Discovery; Penguasaan Konsep.

Abstract: This study aims to describe the increase in students' mastery of concepts and KPS as well as the implementation of teacher learning in science learning class VIIID SMP Kartika XX-6 Kendari using the discovery model. This type of research is the PTK. The subjects in this study were all 26 students of the 2018/2019 academic year. The research data is concept mastery data obtained from tests and KPS obtained from observation sheets. The data were analyzed by using descriptive statistics. The results of data analysis showed that: 1) the mean value of concept mastery in the first cycle was 70.07 with a standard deviation of 9.34, while in the second cycle the mean value of concept mastery was 77.50 with a standard deviation of $5.55 ; 2)$ the percentage of aspects of science process skills in the first cycle was $50.55 \%$ in the sufficient category, while in the second cycle, $73.41 \%$ was in the good category; and 2) the mean value of the implementation of teacher learning in the first cycle was 2.8 and the second cycle was 3.57.

Keywords: Science Process Skills; Learning Model Discovery; Concept Mastery.

\section{PENDAHULUAN}

Pada umumnya seorang peserta didik memilki keterampilan yang berbeda-beda dalam menyikapi suatu persoalan yang berhubungan dengan materi yang akan mereka pelajari. Baik itu dari pengamatan maupun eksperimen sehingga, mereka perlu dibimbing untuk mengembangkan potensi diri mereka karena dengan keterampilan yang baik tentu akan memberikan hasil yang baik pula. Dalam mempelajari Ilmu Pengetahuan Alam (IPA) khususnya fisika, peserta didik dituntut untuk terampil dalam menanggapi berbagai persoalan sehingga akan berdampak pada penguasaan konsep mereka sesuai dengan harapan guru sebagai tenaga pendidik. Pada kenyataannya peserta didik belum mampu terampil dalam proses pembelajaran hal ini juga didukung dengan cara mengajar guru yang masih mempertahankan kenyamanan mereka dengan kurikulum terdahulu. Oleh karena itu, ketika proses yang berlangsung kurang baik maka akan berdampak pada penguasaan konsep mereka pula.

Kondisi kelas VIII Sekolah Menengah Pertama (SMP) Kartika XX-6 Kendari saat ini yaitu terdiri atas 8 kelas dan jumlah guru IPA-Fisika 2 orang dengan jam masuk siang. Berdasarkan hasil wawancara dengan Guru IPA kelas VIII SMP Kartika XX-6 Kendari pada tahun ajaran 2017/2018 dari keseluruhan materi IPA-Fisika materi yang paling rendah nilai rata-rata ulangan hariannya yaitu materi cahaya dan alat optik. Kemudian kelas yang nilai ulangan hariannya paling rendah yaitu kelas VIII $_{D}$ di antara kelas yang lain dimana dari jumlah 
keseluruhan 29 peserta didik hanya 8 orang yang tuntas (terlampir). Hal ini terjadi karena pembelajaran masih bersifat konvensional meskipun telah diterapkan $\mathrm{K}-13$ sehingga penguasaan konsep peserta didik kurang padahal SMP Kartika XX-6 Kendari merupakan sekolah dengan akreditasi A. Selain wawancara, guru IPA juga mengisi angket keterampilan proses sains peserta didik dimana dari 9 keterampilan proses sains (KPS), peserta didik hanya dapat melakukan pengamatan, melakukan pengelompokkan, menafsirkan dan mengajukan pertanyaan, sedangkan untuk merencanakan percobaan, merumuskan hipotesis, menggunakan alat dan bahan, menerapkan konsep dan mengkomunikasikan hasil jarang dilakukan, dikarenakan peserta didik jarang melakukan percobaan meskipun telah disediakan KIT Optik. Hal ini menunjukkan bahwa guru belum mengembangkan KPS peserta didik pada saat proses pembelajaran.

Oleh karena itu, diperlukan model pembelajaran yang dapat meningkatkan kemampuan KPS dan juga penguasaan konsep peserta didik. Salah satu model pembelajaran yang dapat menjadi alternatif adalah model pembelajaran discovery. Menurut Unal \& Ergin (2006), pembelajaran dengan model discovery dianggap paling efektif dalam pembelajaran sains karena peserta didik ditolong untuk mencari dan menemukan sesuatu secara sistematis, kritis, logis dan analitis sehingga dengan penuh keyakinan peserta didik dapat merumuskan sendiri penemuannya. Peserta didik yang diajarkan menggunakan model discovery memiliki keterampilan lebih baik dibanding dengan pembelajaran konvensional. Kemudian penting bagi guru untuk menerapkan model pembelajaran discovery agar peserta didik dapat berpikir kritis dalam menkontruksi suatu pengetahuan.

Menurut Bruner (dalam Mushlihin, 2012) beberapa kelebihan dari model pembelajaran discovery adalah sebagai berikut: model pembelajaran discovery dianggap membantu peserta didik mengembangkan atau memperbanyak persediaan dan penguasaan keterampilan dan proses kognitif peserta didik. Kekuatan dari proses penemuan datang dari usaha untuk menemukan, jadi seseorang belajar bagaimana belajar itu sebenarnya dengan model pembelajaran discovery, pengetahuan yang diperoleh sangat bersifat pribadi. Model pembelajaran discovery menyebabkan peserta didik mengarahkan sendiri cara belajarnya, sehingga ia lebih merasa terlibat dan bermotivasi sendiri untuk belajar dan mengembangkan potensi intelektual.
Peserta didik hanya akan dapat mengembangkan pikirannya dengan berpikir, dengan menggunakan pikiran itu sendiri.

Materi cahaya akan sangat cocok menggunakan model pembelajarn discovery. Hal ini sesuai dengan Penelitian Nasri, dkk (2015), pembelajaran yang dilakukan dengan menerapkan model discovery terbimbing dapat meningkatkan hasil belajar peserta didik pada materi cahaya dan mata. (Mirasi, dkk, 2013) menyatakan rata-rata penguasaan konsep dengan menggunakan model pembelajaran discovery terbimbing lebih tinggi daripada rata-rata peguasaan konsep dengan model pembelajaran lain. Kegiatan belajar dan mengajar dengan menggunakan model pembelajaran discovery menuntut guru lebih kreatif menciptakan situasi yang dapat membuat peserta didik belajar aktif menemukan pengetahuan sendiri. Mengaplikasikan model pembelajaran discovery, guru yang berperan harus membimbing dan memberikan kesempatan kepada peserta didik untuk belajar secara aktif, sebagaimana pendapat guru harus dapat membimbing dan mengarahkan kegiatan belajar peserta didik sesuai dengan tujuan. Penelitian ini mengarahkan peserta didik untuk memiliki pengetahuan kognitif dan melatih keterampilan. Keterampilan dalam hal ini adalah keterampilan proses sains.

Berdasarkan latar belakang masalah yang diuraikan, peneliti telah mengkaji tentang "Penerapan Model Pembelajaran Discovery untuk Meningkatkan Keterampilan Proses Sains dan Penguasaan Konsep IPA Materi Pokok Cahaya dan Alat Optik Peserta Didik Kelas VIII D SMP Kartika XX-6 Kendari”.

\section{METODE}

Jenis penelitian ini merupakan Penelitian Tindakan Kelas (PTK) dengan menerapkan model pembelajaran discovery sebagai alternatif tindakan untuk meningkatkan keterampilan proses sains dan penguasaan konsep pada materi pokok cahaya dan alat optik dalam ranah pengetahuan peserta didik. Jenis penelitian ini digunakan untuk mengetahui keterampilan proses sains dan penguasaan konsep IPA peserta didik Kelas VIII SMP Kartika XX-6 Kendari. Hasil penelitian ini telah diperoleh dengan mengumpulkan data hasil observasi keterampilan proses sains dan hasil tes penguasaan konsep di akhir siklus I dan siklus II. 
Yang telah menjadi subjek penelitian ini adalah peserta didik kelas VIII $_{D}$ SMP Kartika XX-6 Kendari yang terdaftar pada semester II dalam ajaran 2018/2019 dengan jumlah peserta didik 26 orang yang terdiri dari 11 orang laki-laki 15 orang perempuan. Penelitian ini telah dilaksanakan pada semester genap tahun pelajaran 2018/2019 dimulai 14 Maret 2019 sampai dengan 6 April 2019 di SMP Kartika XX-6 Kendari Provinsi Sulawesi Tenggara.

\section{HASIL PENELITIAN DAN PEMBAHASAN 1. Keterampilan Proses Sains}

Data keterampilan proses sains peserta didik kelas VIII $_{D}$ SMP Kartika XX-6 Kendari setelah melakukan kegiatan pembelajaran dengan model pembelajaran discovery diperoleh menggunakan lembar observasi keterampilan proses sains dengan cara observer memberikan skor pada setiap aspek keterampilan proses sains yang dilakukan oleh peserta didik sesuai dengan kriteria yang telah ditentukan dalam pedoman penskoran. Siklus I terdiri dari dua kali pertemuan dan siklus II terdiri dari tiga kali pertemuan. Untuk lebih jelasnya deskripsi nilai rata-rata KPS peserta didik pada siklus I dan siklus II dapat dilihat pada Gambar 1.

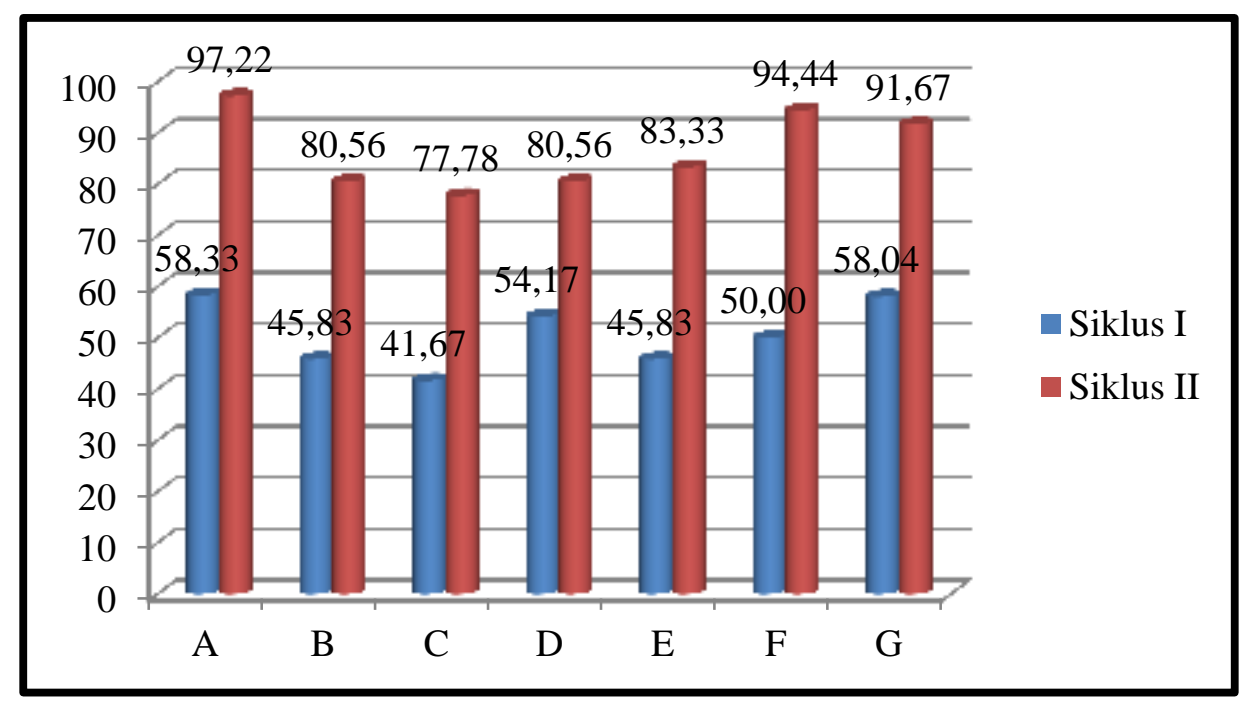

Gambar 1. Grafik Nilai Tiap Aspek KPS Peserta Didik Siklus I dan Siklus II

Keterangan:

Aspek-aspek keterampilan proses sains peserta didik
$\mathrm{A}=$ mengamati;
$\mathrm{B}=$ merumuskan masalah;
$\mathrm{C}=$ merumuskan hipotesis;
$\mathrm{D}=$ merencanakan percobaan/kegiatan mengumpulkan informasi;
$\mathrm{E}=$ melakukan percobaan/kegiatan mengumpulkan informasi;
$\mathrm{F}=$ menganalisis data;
$\mathrm{G}=$ menyimpulkan dan mengkomunikasikan.

Berdasarkan Tabel 1 dapat dilihat bahwa pada siklus I presentase KPS yang diperoleh peserta didik yaitu $50,55 \%$ termasuk dalam kategori cukup, dimana satuan KPS peserta didik tertinggi terdapat pada aspek mengamati dengan nilai presentase sebesar 58,33\% namun berada dalam kategori cukup dan yang terendah adalah aspek merumuskan hipotesis dengan presentase $41,67 \%$ yang juga dalam kategori cukup.

Pada siklus II terlihat bahwa setiap aspek yang diamati mengalami peningkatan. KPS peserta didik tertinggi di siklus I yaitu dari 58,33\% meningkat 
menjadi 97,22\% sedangkan aspek keterampilan yang terendah di siklus I yaitu dari $41,67 \%$ meningkat menjadi 77,78\%, hal ini dapat dilihat pada Tabel 4.1.
Secara jelas, perbandingan rata-rata KPS peserta didik kelas VIII $_{\mathrm{D}}$ SMP Kartika XX-6 Kendari pada siklus I dan II, disajikan pada Gambar 2.

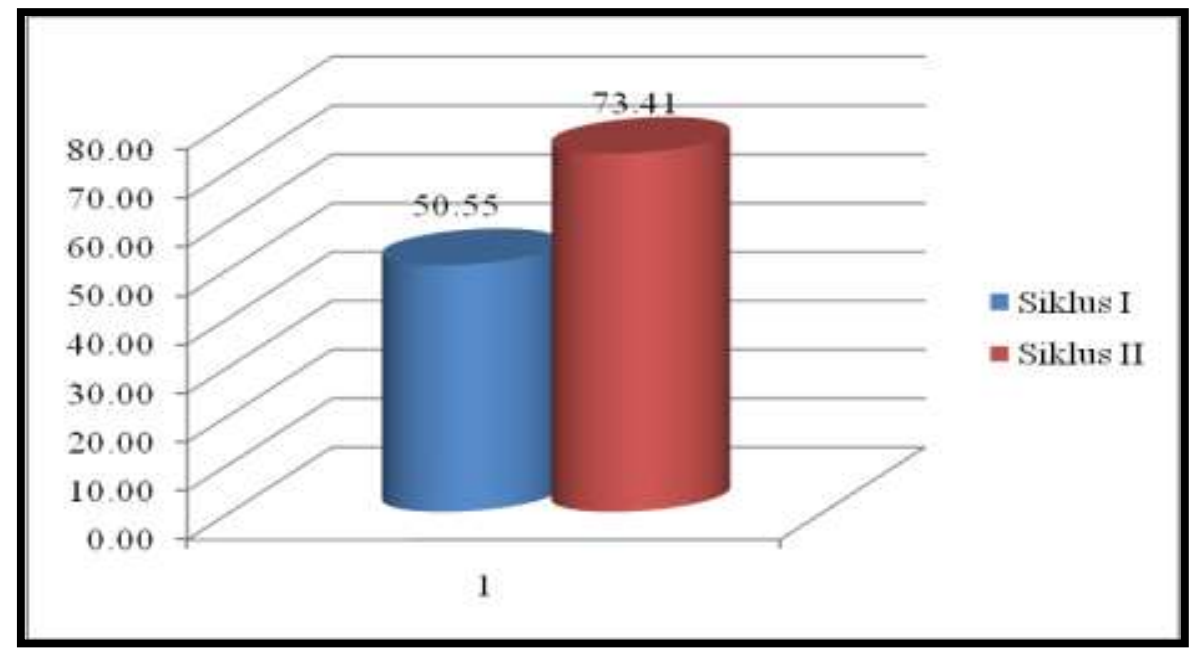

Gambar 2. Grafik Rata-rata Nilai KPS Peserta Didik Siklus I dan Siklus II

Dari Gambar 2, tersebut, menunjukkan adanya peningkatan KPS peserta didik dari siklus I ke siklus II sebesar 22,86\%, dimana nilai presentase KPS peserta didik pada siklus I sebesar 50,55\% dalam kategori cukup mengalami peningkatan pada siklus II menjadi 73,41\% dalam kategori baik.

\section{Data Pelaksanaan Pembelajaran Guru dengan Langkah-langkah Model Pembelajaran Discovery}

Gambaran pelaksanaan pembelajaran guru dalam melaksanakan kegiatan pembelajaran dengan menggunakan model pembelajaran discovery pada materi pokok cahaya dan alat optik diperoleh melalui penilaian guru IPA SMP Kartika XX-6 Kendari (observer) pada aktivitas peneliti dalam mengajar menggunakan lembar observasi aktivitas guru. Selain aspek-aspek tersebut, terdapat beberapa aspek yang sudah bagus pelaksanaannya dan termasuk dalam kategori baik dengan skor rata-rata 3 yaitu aspek: 1) Guru meminta peserta didik untuk melakukan pengamatan; 2) guru membimbing peserta didik untuk mengajukan hipotesis; 3) guru membagi peserta didik menjadi 4 kelompok serta menjelaskan langkah-langkah percobaan yang akan dilakukan; 4) guru membimbing peserta didik melakukan percobaan; 5) guru memberikan kesempatan kepada peserta didik dalam tiap kelompok untuk mempresentasikan hasil diskusinya secara bergantian; 6) guru antusias. dan 7) KBM sesuai dengan skenario pada RPP. Sedangkan aspek yang sudah termasuk dalam kategori sangat baik dengan skor rata-rata 4 yaitu aspek: 1) guru membuka pembelajaran dan mempersiapkan peserta didik;2) guru memberikan motivasi dan apersepsi; 3) guru menyampaikan/menuliskan topik dan tujuan pembelajaran dan 4) guru menyampaikan materi selanjutnya dan mengucapkan salam. skor rata-rata aktivitas guru seluruh aspek yang diperoleh pada siklus I adalah 2,8 dan termasuk dalam kategori baik.

Pada siklus II terlihat bahwa pelaksaaan pembelajaran guru mengalami peningkatan dari siklus I, dimana aspek-aspek yang awalnya termasuk dalam kategori kurang dan cukup dengan skor ratarata 1,5 dan 2 menjadi 3 dan 4 yang termasuk dalam kategori baik dan sangat baik sehingga skor ratarata keseluruhan siklus II menjadi 3,57 yang termasuk dalam kategori sangat baik. Hal ini menunjukkan bahwa guru telah mampu menggunakan model pembelajaran discovery pada materi pokok cahaya dan alat optik dengan baik. Grafik skor rata-rata siklus I dan silklus II dapat dilihat pada Gambar 3. 


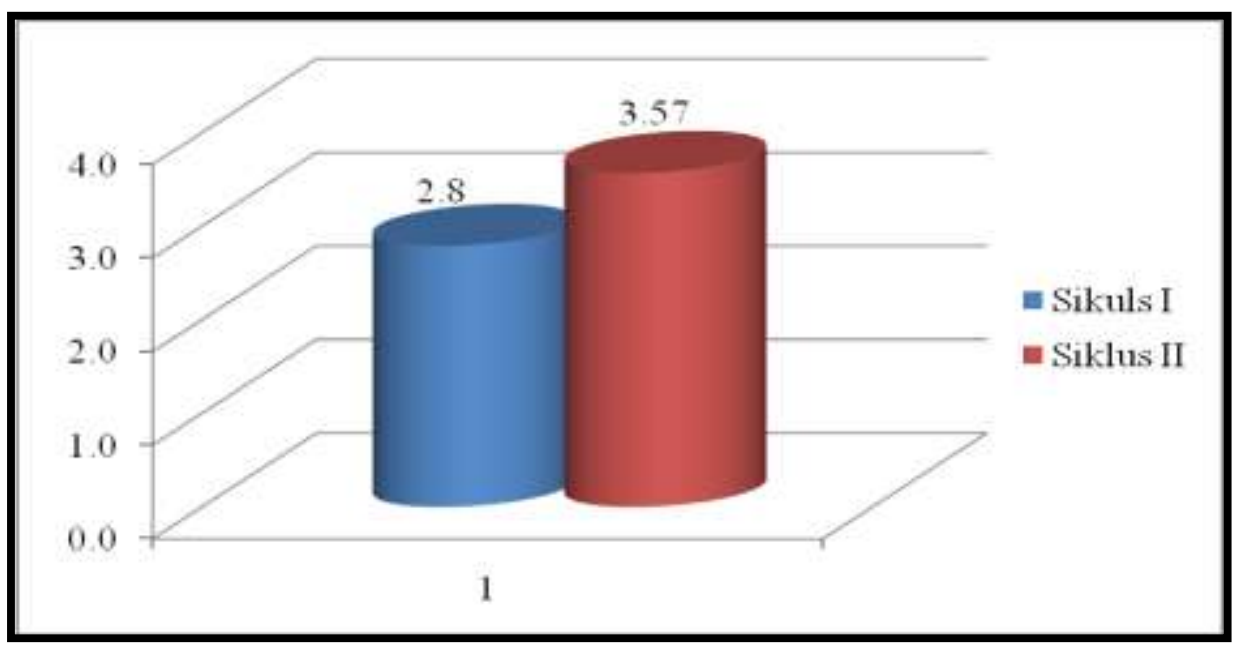

Gambar 3. Grafik Skor Rata-Rata Pelaksanaan Pembelajaran Guru dengan Langkah-langkah Model Discovery pada Siklus I dan Siklus II.

Berdasarkan Gambar 3 tersebut, menunjukkan adanya peningkatan skor rata-rata aktivitas guru dari siklus I menuju siklus II sebesar 0,77 dengan skor rata-rata aktivitas guru pada siklus I sebesar 2,8 dengan kategori baik mengalami peningkatan pada siklus II menjadi 3,57 dengan kategori sangat baik.

\section{Data Penguasaan Konsep Peserta Didik}

Data penguasaan konsep peserta didik dengan model pembelajaran discovery pada materi pokok cahaya dan alat optik diperoleh melalui tes esai yang dilakukan disetiap pertemuan terakhir siklus I dan siklus II. Untuk lebih jelasnya gambaran peningkatan penguasaan konsep peserta didikdari siklus I ke siklus II dapat dilihat pada Gambar 4.

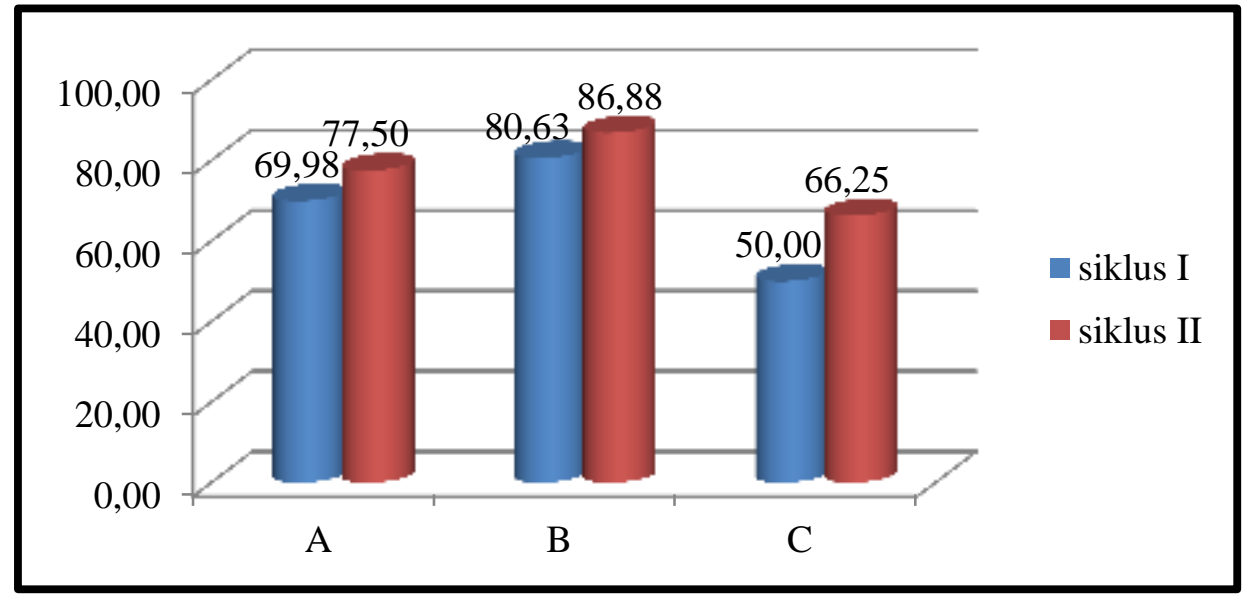

Gambar 4. Grafik Peningkatan Penguasaan Konsep peserta Didik Siklus I dan Siklus II Secara Keseluruhan

Keterangan:

$\begin{aligned} \mathrm{A} & =\text { nilai rata-rata persiklus } \\ \mathrm{B} & =\text { nilai maksimum persiklus } \\ \mathrm{C} & =\text { nilai Minimum persiklus }\end{aligned}$

Dapat dilihat secara jelas peningkatan penguasaan konsep peserta didik kelas $\mathrm{VIII}_{\mathrm{D}}$ materi pokok cahaya dan alat optik dengan model pembelajaran discovery pada Gambar 4. Nilai rata- 
rata yang awalnya 69,98 pada siklus I menjadi 77,50 pada siklus II. Kemudian nilai maksimum 80,63 pada siklus I meningkat menjadi 86,88 dan nilai minimum 50,00 pada siklus I mengalami peningkatan menjadi 66,25 pada siklus II. Selain itu, standar deviasi yang pada siklus I sebesar 9,34 menjadi 5,55 pada siklus II.

\section{Data Ketuntasan Belajar Peserta Didik}

Peningkatan presentasi ketuntasan belajar peserta didik dari siklus I ke siklus II dapat dilihat pada Gambar

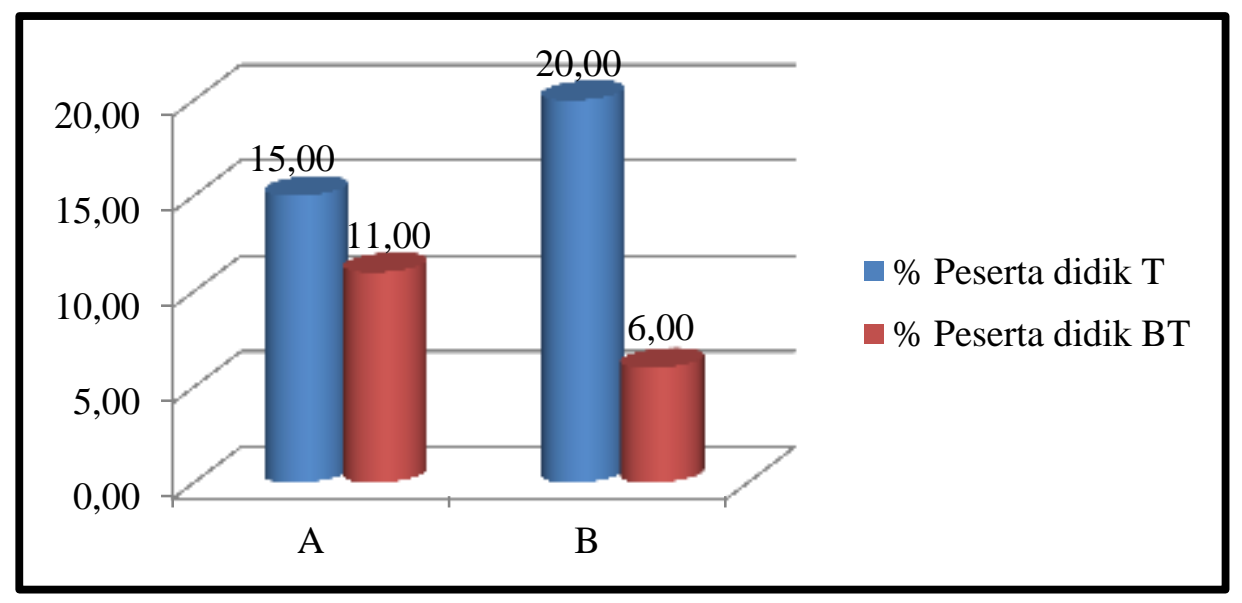

Gambar 5. Grafik Peningkatan Presentasi Ketuntasan Belajar Peserta Didik Siklus I dan Siklu II

Keterangan:

$$
\begin{aligned}
& \mathrm{A}=\text { siklus I } \\
& \mathrm{B}=\text { siklus II }
\end{aligned}
$$

Dapat dilihat pada Gambar 5 adanya peningkatan presentasi ketuntasan belajar peserta didik kelas VIII $_{D}$ materi pokok cahaya dan alat optik dengan model pembelajaran discovery dari siklus I ke siklus II. Pada siklus I presentasi peserta didik yang nilai penguasaan konsepnya telah mencapai nilai KKM (74) dan dikategorikan tuntas berjumlah 15 orang dengan presentasi $57,69 \%$ dan peserta didik yang belum tuntas berjumlah 11 orang dengan presentasi $76,92 \%$ sedangkan pada siklus II peserta didik yang tuntas penguasaan konsepnya mengalami peningkatan menjadi 20 orang dengan presentasi $42,31 \%$ dan peserta didik yang belum tuntas mengalami penurunan menjadi 6 orang dengan presentasi $23,08 \%$. Oleh karena itu, dapat dikatakan hasil yang diperoleh telah memenuhi kriteria keberhasilan tindakan dimana penelitian ini dikatakan berhasil jika presentasi ketuntasan belajar peserta didik secara klasikal $\geq 75 \%$. Dengan demikian penerapan model pembelajaran discovery pada materi pokok cahaya dan alat optik dapat memecahkan masalah peserta didik kelas $\mathrm{VIII}_{\mathrm{D}}$.

\section{PEMBAHASAN}

Penelitian tindakan kelas (PTK) ini dilaksanakan dengan menerapkan model pembelajaran discovery pada materi pokok cahaya dan alat optik yang terdiri dari dua siklus, yaitu siklus I dan siklus II dimana siklus I terdiri dari dua pertemuan dan siklus II terdiri dari tiga pertemuan. Subjek dari penelitian ini adalah seluruh peserta didik kelas VIII $_{D}$ SMP Kartika XX-6 Kendari yang terdiri dari 26 peserta didik, 11 berjenis kelamin laki-laki dan 15 berjenis kelamin perempuan. Data yang dikumpulkan dalam penelitian ini adalah data penguasaan konsep peserta didik yang diperoleh melalui tes penguasaan konsep dan data keterampilan proses sains peserta didik yang diperoleh melalui lembar obeservasi.

Pelaksanaan pembelajaran tiap pertemuan dalam satu silklus memiliki kegiatan pembelajaran yang mencerminkan ciri khas dari model pembelajaran discovery yaitu guru memberikan stimulus atau rangsangan, guru meminta peserta didik untuk mengajukan pertanyaan dan hipotesis, guru membagi peserta didik dalam 4 kelompok belajar heterogen yang terdiri dari 6-7 peserta didik 
dalam satu kelompok, guru membagikan LKPD dan menjelaskan tentang tugas yang akan dikerjakan, guru membimbing peserta didik melakukan percobaan/kegiatan mengumpulkan informasi sesuai dengan petunjuk dalam LKPD, guru membimbing peserta didik mengolah dan menganalisis data serta mengerjakan LKPD berdasarkan hasil percobaan/ kegiatan mengumpulkan informasi, guru membimbing peserta didik melakukan diskusi mengenai kegiatan yang mereka lakukan, dan guru memberikan kesempatan kepada peserta didik untuk memeriksa kembali jawaban dan menjawab rumusan masalah dan hipotesis yang telah dibuat peserta didik. Sebagaian besar aktivitas pembelajaran berpusat pada peserta didik dalam menemukan pemahamanya terhadap materi cahaya dan alat optik yang dipelajari, sementara guru bertugas mengawasi dan membimbing jalannya kegiatan pembelajaran. Ciri khas model pembelajaran tersebut digunakan untuk mengetahui sejauh mana pemahaman peserta didik terhadap materi pembelajaran.

\section{Siklus I}

\section{Keterampilan Proses Sains}

Berdasarkan hasil analisis deskriptif keterampilan proses sains peserta didik pada Tabel 4.1 menunjukkan bahwa presentase aspek keterampilan proses sains peserta didik di siklus I sebesar 50,55\% termasuk dalam kategori kurang. Dalam siklus I aspek keterampilan proses sains peserta didik seperti mengamati, merumuskan masalah, hipotesis, merencanakan percobaan, melakukan percobaan, menganalisis data menyimpulkan dan mengkomunikasikan hasil dalam kategori cukup sehingga semua aspek perlu ditingkatkan lagi. Namun ada beberapa aspek dalam kategori cukup yaitu aspek dan sedangkan dalam kategori kurang yaitu aspek. Rendahnya aspek-aspek tersebut dikarenakan peserta didik tidak terbiasa melakukan kegiatan praktikum secara langsung dan tidak terbiasa mengerjakan LKPD, dimana peserta didik harus merumuskan masalah, hipotesis dan melakukan percobaan. Selain itu, ada beberapa peserta didik yang kurang antusias dalam mengikuti kegiatan pembelajaran.

Solusi yang diupayakan yaitu guru harus berusaha membimbing peserta didik dalam melakukan percobaan secara rinci dan jelas. Selain itu, dalam mengerjakan LKPD guru harus menjelaskan tata cara pengisian LKPD Sehingga antara percobaan yang dilakukan dan mengerjakan LKPD bisa sejalan. Guru juga harus membuat suasana belajar lebih menyenangkan sehingga peserta didik yang kurang antusias menjadi lebih antusias dalam mengikuti kegiatan pembelajaran. Oleh karena itu, akan seimbang antara peserta didik yang antusias dan guru.

\section{Pelaksanaan Pembelajaran Guru}

Hasil analisis deskriptif pelaksanaan pembelajaran guru yang dapat dilihat pada Tabel 4.2 menunjukkan terdapat aspek pengamatan yang termasuk dalam kategori kurang yaitu aspek pembelajaran yang sesuai alokasi waktu. Rendahnya aspek pelaksanaan guru tersebut disebabkan peserta didik masih kurang paham dengan cara menjawab LKPD sehingga guru harus berulang-ulang menjelaskan. Selain itu terdapat alat yang harus digilir sehingga juga menghabiskan banyak waktu. Solusi yang perlukan yaitu guru harus menjelaskan secara rinci mengenai cara mengerjakan LKPD dan alat yang harus gilir harus digunakan berdasarkan waktu yang telah ditentukan dan diperhitungkan oleh guru. Kemudian untuk siklus II guru harus pandai dalam mengelolah kegiatan pembelajaran sehingga sesuai dengan waktu yang telah ditetapkan sebelumnya.

Pelaksanaan pembelajaran guru yang termasuk dalam kategori cukup dengan skor rata-rata 2 yaitu aspek guru meminta peserta didik untuk mengajukan pertanyaan/merumuskan masalah, guru memberikan kesempatan kepada peserta didik dalam melakukan diskusi kelompok untuk menjawab LKPD, guru memberi kesempatan untuk memeriksa kembali jawaban LKPD dan membuktikan benar atau tidaknya hipotesis yang mereka ajukan, guru membimbing peserta didik untuk membuat kesimpulan bersama kelompoknya, guru bersama peserta didik mereview dan menyimpulkan materi yang telah dipelajari dan peserta didik antusias. Rendahnya aktivitas guru tersebut disebabkan guru masih dalam tahap penyesuaian diri untuk mengajar, sehingga ada beberapa pelaksanaan yang semestinya dilakukan tatapi tidak dilaksanakan. Hal ini juga dipengaruhi oleh penggunaan waktu yang kurang optimal terutama pada proses melakukan kegiatan eksperimen dan diskusi kelompok untuk mengerjakan LKPD yang membutuhkan waktu lebih dari yang direncanakan sehingga kegiatan penutup pembelajaran menggunakan waktu yang minim hal ini menyebabkan dalam kegiatan guru memberi kesempatan untuk memeriksa kembali LKPD dan menyimpulkan hasil diskusi serta guru bersama peserta didik mereview serta materi yang telah dipelajari menjadi kurang optimal. 


\section{Pengetahuan Konsep dan Ketuntasan Belajar}

Rendahnya nilai rata-rata keterampilan proses sains peserta didik pada aspek yang telah dijelaskan diatas dan beberapa aspek pelaksanaan pembelajaran guru yang tidak dilaksanakan secara maksimal terutama terutama penggunaan waktu yang kurang optimal berdampak pada rendahnya penguasaan konsep beberapa peserta didik. Dimana, berdasarkan analisis deskriptif penguasaan konsep peserta didik pada siklus I seperti pada Tabel 4.4, diketahui nilai rata-rata penguasaan konsep peserta didik sebesar 70,07 dan terdapat 11 orang peserta didik atau $42,31 \%$ nilainya masih di bawah KKM yang ditentukan oleh sekolah yaitu $\geq 74$ (belum tuntas) dan 15 orang peserta didik atau 57,69\% yang memperoleh nilai $\geq 74$ (tuntas). Berdasarkan kriteria keberhasilan tindakan, dimana presentasi peserta didik yang sudah tuntas harus $\geq 75 \%$ maka nilai pengetahuan konsep yang diperoleh peserta didik belum memenuhi kriteria keberhasilan tindakan. Akan tetapi, hasil yang diperoleh pada siklus I ini belum bisa dikatakan baik karena lebih tinggi dibandingkan dengan rata-rata nilai ulangan harian materi pokok cahaya dan alat optik peserta didik kelas VIII $_{\text {D }}$ tahun ajaran 2017/2018 sebesar 70,31. Kemudian untuk standar deviasi diperoleh 9,24. Hasil yang diperoleh tersebut tidak sejalan dengan skor rata-rata aktivitas guru yang diperoleh yaitu sebesar 2,8 dengan kategori baik. Oleh karena itu guru harus menekankan penguasaan konsep pada materi selanjutnya dan harus memberikan banyak latihan soal terutama jenis soal analisis atau perhitungan. Selain itu, guru juga harus memberikan banyak motivasi belajar agar peserta didik meningkatkan rasa ingin tahunya terhadap suatu fenomena yang dipelajari.

\section{Refleksi}

Dari masalah tersebut peneliti dan guru mata pelajaran melakukan analisis dan refleksi terhadap faktor-faktor yang menyebabkan kurangnya beberapa pelaksanaan pembelajaran guru dan keterampilan proses sains peserta didik dalam model pembelajaran discovery ini. Beberapa aspek pelaksanaan guru maupun keterampilan proses sains peserta didik yang masih butuh peningkatan sebagai berikut.

1) Guru kurang dalam meminta peserta didik untuk mengajukan pertanyaan.

2) Guru kurang memberikan kesempatan peserta didik dalam melakukan diskusi, dalam mengerjakan LKPD maupun memeriksa kembali LKPD.
3) Guru kurang membimbing dalam menyimpulkan LKPD.

4) Guru kurang dalam mereview dan menyimpulkan materi secara keseluruhan yang telah dipelajari.

5) Peserta didik kurang antusias.

6) Peserta didik masih belum menyesuaikan diri dengan model pembelajaran baru (model pembelajaran discovery).

7) Peserta didik sebagian terlihat penasaran dengan percobaan yang dilakukan namun hanya sebagian kecil dan rata-rata hanya siswa perempuan yang serius mengikuti.

Setelah melakukan analisis dan refleksi terhadap setiap aspek-aspek dalam model pembelajaran discovery dan keterampilan proses sains, peneliti bersama guru mata pelajaran melakukan langkahlangkah perbaikan untuk siklus II yakni sebagai berikut.

1) Guru hendaknya lebih banyak memberi kesempatan kepada peserta didik untuk mengajukan pertanyaan setelah memberikan penjelasan.

2) Guru hendaknya memberi kesempatan peserta didik untuk berdiskusi dalam mengerjakan LKPD maupun memeriksanya kembali.

3) Guru hendaknya membimbing peserta didik untuk membuat kesimpulan bersama kelompoknya dalam mengerjakan LKPD.

4) Guru hendaknya bersama peserta didik mereview dan menyimpulkan materi yang dipelajari.

5) Dengan guru memberikan motivasi belajar betapa pentingnya mempelajari cahaya dan alat optik peserta didik dapat antusias belajar.

6) Dengan guru memberikan bimbingan dan arahan tentang mekanisme pembelajaran peserta didik dapat mengikuti pembelajaran dengan baik dan mulai terbiasa.

7) Dengan guru memperagakan percobaan yang dilakukan dan selalu menunjuk peserta didik laki-laki untuk menebak apa yang akan terjadi selanjutnya tentang percobaan yang dilakukan. Sehingga peserta didik terlihat penasaran dan ingin segera tahu.

Berdasarkan hasil analisis dan refleksi diatas, guru akan melakukan beberapa perbaikan untuk diterapkan pada siklus II serta melibatkan peserta didik dalam setiap kegiatan pembelajaran sehingga meningkatkan daya pikir dan kemampuan peserta didik menemukan pemahamannya terhadap materi. Sehingga diharapkan pada pertemuan selanjutnya diperoleh peningkatan pelaksanaan pembelajaran guru dalam pembelajaran dan berdampak pada 
meningkatnya keterampilan proses sains dan penguasaan peserta didik.

\section{Siklus II \\ 1. Keterampilan Proses Sains}

Kegiatan pembelajaran pada siklus II ini dilakukan dengan guru memperbaiki aktivitas mengajarnya terutama pada aspek aktivitas membimbing dan mengarahkan peserta didik melakukan percobaan atau diskusi kelompok serta mengerjakan LKPD. Yang menjadi perhatian guru pada siklus II ini adalah membimbing dan menjelaskan secara lebih detail pada askpek indikator KPS yang presentasenya masih kurang di siklus I, khususnya aspek merumuskan masalah, merumuskan hipotesis, dan melakukan percobaan. Selain itu, indikator KPS lainnya juga tidak luput dari perhatian guru. Peserta didik yang dianggap lebih pintar dalam setiap kelompok memimpin anggota kelompoknya dalam melakukan kegiatan eksperimen dan mengerjakan LKPD sesuai dengan arahan dari guru. Peserta didik juga mulai terbiasa dalam melakukan kegiatan eksperimen dan mulai memahami bagaimana mengerjakan LKPD. Berdasarkan observasi observer diperoleh gambaran bahwa keterampilan proses sains peserta didik yang diajar dengan model pembelajaran discovery pada siklus II termasuk dalam kategori baik dengan presentase $73,41 \%$ hal ini menunjukkan adanya peningkatan nilai rata-rata keterampilan proses sains peserta didik dari siklus I yang dapat dilihat pada Tabel 4.1. Adanya peningkatan nilai rata-rata peserta didik ini menunjukkan bahwa peserta didik sudah mulai terbiasa dalam melakukan kegiatan eksperimen dan mengerjakan LKPD dengan model pembelajaran discovery. Meskipun peninggkatan tidak berbeda jauh dengan nilai rata-rata sebelumnya namun, sudah mencapai nilai dalam kategori baik.

Pada siklus II semua aspek keterampilan proses sains peserta didik meningkat, peningkatan terlihat pada aspek keterampilan proses sains mengamati dengan presentase $97,22 \%$ dengan kategori sangat baik, aspek merumuskan masalah dengan presentase 80,56\% dengan kategori baik, aspek merumuskan hipotesis dengan presentase $77,78 \%$ dengan kategori baik, aspek merencanakan percobaan/kegiatan diskusi dengan prsentase $80,56 \%$ kategori sangat baik, aspek melakukan percobaan/kegiatan diskusi dengan presentase $83,33 \%$ dengan kategori baik, aspek menganalisis data dengan presentase $94,44 \%$ kategori sangat baik, dan aspek menyimpulkan dan mengkomunikasikan dengan presentase 93,33\% kategori sangat baik. Menurut peneliti peningkatan keterampilan proses sains peserta didik disebabkan peserta didik sudah mulai terbiasa mengerjakan LKPD sehingga sedikit demi sedikit memahami bagaimana mengerjakan LKPD berdasarkan hasil eksperimen atau kegiatan yang mereka lakukan, selain itu kegiatan eksperimen pada siklus I lebih sulit dibandingkan kegiatan eksperimen pada siklus II. Dimana pada siklus I peserta didik banyak melakukan kegiatan eksperimen seperti merangkai percobaan cermin dan lensa dan membuktikan sifatsifat cahaya sementara pada siklus II peserta didik hanya melakukan satu kegiatan eksperimen dan selanjutnya non eksperimen dengan berdiskusi untuk mengumpulkan data-data melalui kehidupan seharihari mereka dan melalui bahan ajar yang mereka miliki.

Model pembelajaran discovery ditandai dengan peserta didik terlibat secara aktif dalam kegiatan pembelajaran, dimana peserta didik menemukan sendiri pemahamannya terhadap materi yang dipelajari oleh karena itu model pembelajaran ini sangat cocok dengan keterampilan proses sains yang melatih peserta didik merumuskan masalah, hipotesis, merencanakan percobaan, melakukan percobaan, menganalisis data dan menyimpulkan hasil percobaan/diskusi kelompok. Hal ini, sejalan menurut Hafid (2017) dalam penelitiannya menunjukkan adanya berbedaan yang signifikan antara keterampilan proses sains peserta didik kelas V SDN 1 Ambekairi yang diajar dengan model pembelajaran discovery dan pembelajaran langsung karena keterampilan proses sains peserta didik di kelas dengan model pembelajaran discovery lebih tinggi dibandingkan dengan kelas yang menggunakan model pembelajaran langsung. Penelitian lain juga dilakukan oleh Lete dkk (2016) menyatakan model pembelajaran discovery merupakan model pembelajaran yang dapat menumbuh kembangkan keterampilan proses sains peserta didik secara efektif dengan cara melibatkan peserta didik secara aktif dalam setiap proses.

\section{Pelaksanaan Pembelajaran Guru}

Pelaksanaan tindakan pada siklus II dilakukan dengan memperbaiki kekurangan pada siklus I, dimana beberapa aspek pelaksanaan pembelajaran guru yang kurang diperhatikan atau tidak dilaksanakan guru meminta peserta didik untuk mengajukan pertanyaan, guru memberikan kesempatan kepada peserta didik dalam melakukan diskusi kelompok untuk menjawab LKPD, guru memberi kesempatan untuk memeriksa kembali jawaban LKPD dan membuktikan benar atau tidaknya hipotesis yang mereka ajukan, guru 
membimbing peserta didik untuk membuat kesimpulan bersama kelompoknya, guru bersama peserta didik mereview dan menyimpulkan materi yang telah dipelajari pada siklus II begitupun dengan pelaksanaan guru yang sudah dilaksanakan pada siklus I tetap dipertahankan atau ditingkatkan pada siklus II. Pada siklus II menunjukkan adanya peningkatan skor rata-rata pelaksanaan guru menjadi 3,57 dengan kategori sangat baik. Aspek pembelajaran yang sesuai alokasi waktu yang termasuk dalam kategori kurang pada siklus I dengan skor rata-rata 1,5 meningkat menjadi 3 dengan skor rata-rata 3,0. Guru sudah dapat mengelolah kegiatan pembelajaran sesuai dengan waktu yang telah ditentukan. Aspek-aspek pelaksanaan pembelajaran guru lainnya juga mengalami peningkatan yang dapat dilihat pada Tabel 4.2. Peningkatan rata-rata pelaksanaan guru menandakan bahwa kelemahan-kelemahan yang terdapat pada siklus I dapat teratasi sehingga guru perlu mempertahankan keterampilan dalam menggunakan model pembelajaran discovery.

\section{Penguasaan Konsep dan Ketuntasan Belajar}

Setelah melakukan perbaikan terhadap pelaksanaan pembelajaran guru yang masih kurang pada siklus I, penguasaan konsep dan ketuntasan belajar peserta didik menjadi meningkat pada siklus II. Pada siklus II ini guru memperhatikan dan melaksanakan langkah-langkah kegiatan pembelajaran yang tidak dilaksanakan pada siklus I. Kemudian guru menjelaskan secara lebih detail lagi kepada masing-masing peserta didik dalam mengerjakan LKPD terutama pada indikator yang masih kurang pada siklus I, yaitu indikator merumuskan masalah, merumuskan hipotesis, dan menganalisis data. Peserta didik juga sudah mulai terbiasa dalam melakukan kegiatan eksperimen dan mengerjakan LKPD. Sehingga hal tersebut berdampak pada penguasaan konsep yang dimiliki peserta didik terhadap materi yang dipelajari meningkat dari siklus I yang dapat dilihat pada Tabel 6, dimana diperoleh nilai rata-rata peguasaan konsep peserta didik pada siklus II sebesar 77,50, hasil yang diperoleh ini lebih tinggi dibandingkan pada siklus I. Pada siklus ini terdapat 20 orang peserta didik atau $76,92 \%$ yang memperoleh nilai $\geq$ 74 (tuntas) sisanya masih $<74$. Berdasarkan kriteria keberhasilan tindakan dimana jika presentasi ketuntasan belajar peserta didik secara klasikal $\geq 75$ $\%$ maka penguasaan konsep yang diperoleh peserta didik pada siklus II ini sudah memenuhi kriteria keberhasilan tindakan. Sehingga dapat dikatakan penelitian yang dilakukan telah berhasil. Selain itu, untuk standar deviasi yang diperoleh pada siklus II yaitu 5,55 hal ini berbeda dengan siklus I yaitu 9,24 sehingga dapat dikatakan bahwa penyimpangan data penguasaan konsep semakin kecil.

Peningkatan yang terjadi menunjukkan bahwa guru telah melakukan perbaikan berdasarkan analisis dan refleksi yang telah dilakukan sebelumnya pada siklus I. Peningkatan yang terjadi juga tidak terlepas dari peran peserta didik dalam mengikuti pembelajaran secara lebih aktif dengan mau bekerjasama bersama anggota kelompoknya. Peningkatan keterampilan proses sains peserta didik dan prolehan penguasaan konsep peserta didik membuktikan bahwa model pembelajaran discovery dapat memberikan pengaruh positif bagi proses pembelajaran. Dengan demikian dapat dibuktikan bahwa penerapan model pembelajaran discovery dapat meningkatkan keterampilan proses sains, dan penguasaan konsep peserta didik kelas VIII $_{D}$ SMP Kartika XX-6 Kendari materi pokok cahaya dan alat optik.

Berdasarkan penelitian sebelumnya, yang telah dilakukan oleh Sarmiati (2015), hasil penelitiannya menunjukkan bahwa adanya peningkatan keterampilan proses sains peserta didik yang diajar dengan menggunakan model pembelajaran discovery. Hasil tersebut sejalan dengan penelitian yang dilakukan oleh Hadiono dan Hidayanti (2016), dimana dalam penelitiannya menunjukkan hasil dengan penerapan model pembelajaran discovery dapat meningkatkan persentase ketuntasan belajar peserta didik kelas $\mathrm{VIII}_{\mathrm{D}}$ SMPN 2 Kamal sebesar 11,32\%.

\section{KESIMPULAN}

Penguasaan konsep IPA materi pokok cahaya dan alat optik peserta didik kelas VIII ${ }_{D}$ SMP Kartika XX-6 Kendari yang diajar dengan menggunakan model pembelajaran discovery mengalami peningkatan dimana pada siklus I diperoleh nilai rata-rata sebesar 70,07 dengan standar deviasi sebesar 9,24 sedangkan pada siklus II diperoleh nilai rata-rata sebesar 77,50 dengan standar deviasi sebesar 5,55. Keterampilan proses sains peserta

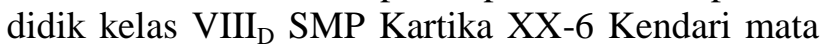
pelajaran IPA materi pokok cahaya dan alat optik dengan menggunakan model pembelajaran discovery mengalami peningkatan sebesar $22,86 \%$ dimana pada siklus I diperoleh presentase sebesar $50,55 \%$ sedangkan pada siklus II diperoleh presentase sebesar $73,41 \%$. Ketuntasan belajar IPA materi pokok cahaya dan alat optik peserta didik kelas VIII $_{D}$ SMP Kartika XX-6 Kendari yang diajar 
menggunakan model pembelajaran discovery mengalami peningkatan sebesar $19,23 \%$, dimana pada siklus I persentase ketuntasan belajar peserta didik sebesar 57,92 \% sedangkan pada siklus II sebesar 76,69\% sehingga memenuhi kriteria keberhasilan tindakan secara individu dan klasikal. Pelaksanaan pembelajaran guru pada pembelajaran IPA materi pokok cahaya dan alat optik kelas VIII $_{\mathrm{D}}$ SMP Kartika XX-6 Kendari yang diajarkan dengan menggunakan model pembelajaran discovery mengalami peningkatan dimana pada siklus I nilai rata-rata sebesar 2,8 sedangkan pada siklus II sebesar 3,57.

\section{DAFTAR PUSTAKA}

Abruscato. 1994. Teaching Children Science A Discovery Approach Fourth Edition. Tokyo : University of Vernon

Arikunto, Suharsimi. 2005. Manajemen Penelitian. Jakarta : Penerbit PT Rineka Cipta.

BSNP. 2006. Permendiknas No.22 tahun 2006 Tentang Standar Isi untuk Satuan Pendidikan Dasar dan Menengah. Jakarta : Depdiknas.

Dahar, R.W. 1998. Teori Teori Belajar. Jakarta: Erlangga.

Darmadi. 2017. Pengembangan Model dan Metode Pembelajaran dalam Dinamika Belajar Siswa. Yogyakarta : Deepublis.

Dimyati dan Mudjiono. 2002. Belajar dan Pembelajaran. Jakarta : Rineka Cipta dan Depdikbud.

Fathurrohma. 2017. Belajar dan Pembelajaran Modern: Konsep Dasar, Inovasi, dan Teori Pembelajaran. Yogyakarta: Penerbit Garudhawaca.

Sagala, Syaiful. (2013). Konsep dan Makna Pembelajaran. Bandung : Alvabeta.

Sudjana. 2006. Bandung : Metoda Statistika. Tarsito.

Sulistyorini, Sri. 2007. Pembelajaran IPA Sekolah Dasar. Semarang : Tiara Wacana.

Suprijono. 2009. Cooperative Learning, Teori \& Aplikasi PAIKEM. Surabaya: Pustaka Pelajar.

Trianto. 2007. Model-model Pembelajaran Inovatif. Jakarta : Grasindo.

Usman. 2001. Upaya Optimalisasi Kegiatan Belajar Mengajar. Bandung : Remaja Rosdakarya.

Hadiono dan N.A Hidayati. 2016. Penerapan Model Pembelajaran Discovery Learning untuk Meningkatkan Motivasi dan Hasil Belajar
Siswa Kelas VIII-D SMPN 2 Kamal Materi Cahaya. Universitas Trunojoyo.

Nurhasanah. 2016. Penggunaan Tes Keterampilan Proses Sains (KPS) Siswa dalam Pembelajaran Konsep Kalor dengan Model Inkuiri Terbimbing [Skripsi]. Universitas Uin Syarif Hidayatullah, Jakarta.

Sarmiati. 2015. Meningkatkan Keterampilan Proses Sains dan Ketuntasan Belajar Siswa Kelas $V I I I_{B}$ SMA Negeri 1 Samaturu Dengan Menerapkan Model Pembelajaran Penemuan Materi Cahaya [skripsi]. Universitas Halu Oleo, Kendari.

Azizirrahim, dkk. 2015. Penerapan Pendekatan Keterampilan Proses Sains Dalam Model Pembelajaran Guided Discovery untuk Meningkatkan Hasil Belajar IPA Fisika Pada Siswa Kelas VIIA SMPN 8 Mataram Tahun Ajaran 2015/2016. Jurnal Pendidikan Fisika dan Teknologi Volume 1 No 4. Diakses pada tanggal 22 oktober 2018.

Furoidah. 2017. Implementasi Model Discovery Learning Disertai Lembar Kerja Siswa Dalam Pembelajaran Fisika Siswa SMA. Universitas Jember, Jawa Timur. Jurnal Pembelajaran Fisika, Vol 6 No. 3. Diakses pada tanggal 22.

Khaerunnisa. 2016. Analisis Keterampilan Proses Sains (Fisika) SMA Di Kabupaten Jeneponto. Junal pendidikan Fisika UMM Volume 5 Nomor 3. Universitas Muhammadiyah Makasar. Diakses pada tanggal 3 November 2018.

Kurniasih. 2015. Ragam Pengembangan Model Pembelajaran untuk Meningkatkan Profesionalitas Guru. Surabaya: Kata Pena. Madura. Vol. 3, No. 3.

Nasri. 2015. Penerapan Model Penemuan Terbimbing Dalam Meningkatkan Aktivitas dan Hasil Belajar IPA Siswa Kelas VIII MTsN Sigli Pada Konsep Cahaya dan Mata. Jurnal Pendidikan Sains Indonesia, Vol. 03, No.01. Universitas Syiah Kuala, Aceh. Diakses pada tanggal 3 November 2018.

Sutopo. 2016. Peningkatan Keterampilan Proses Sains Siswa Melalui Pembelajaran Discovery Topik Tekanan Hidrostatis. Jurnal Pros. Semnas Pendidikan IPA Pasca Sarjana UM Volume 1. Universitas Negeri Malang, Malang. Diakses pada tanggal 22 Oktober 2018.

Mushlihin. 2012. Kelebihan dan kekurangan model pembelajaran guided discovery. Diunduh 
dari

http://referensimakalah.com/2012/10/kelebih an-dan kekurangan model-pembelajaranguided-discovery.html.

Sasanti, dkk. 2017. Pengembangan LKS Dengan Model Inquiry Discovery Learning (IDL) Untuk Melatihkan Keterampilan Proses Sains Pada Pokok Bahasan Listrik Dinamis Di SMAN 5 Banjarmasin. Jurnal Berkala Pendidikan FisikaVolume 5 Nomor 1. Diakses pada tanggal 22 Oktober 2018.
Unal, G. \& Ergin, O. 2006. Bulus Yoluyla Fen Ogretiminin Ogrencilerin Akademik Basarilarina, Ogrenme Yaklasimlarina ve Tutumlarina Etkisi. Journal of Turkish Science Education, 3(1), 36-52. Diakses pada tanggal 3 November.

Widodo. 2009. Keterampilan Proses Sains. Tersedia di http:// www.wordpress.com/ (diakses 3 November 2018). 